\title{
OPTIMIZATION OF FACTORS OF MANAGING PRODUCTIVE PROCESSES OF WINTER WHEAT IN THE FOREST-STEPPE
}

\author{
M. M. Marenych ${ }^{1}$, V. F. Kaminsky ${ }^{2}$, C. Yu. Bulygin ${ }^{3}$, V. V. Hanhur ${ }^{1}$, I. V. Korotkova ${ }^{1 *}$, \\ S. O. Yurchenko ${ }^{1}$, A. V. Bahan ${ }^{1}$, S. V. Taranenko ${ }^{1}$, V. V. Liashenko ${ }^{1}$ \\ ${ }^{1}$ Poltava State Agrarian Academy, 1/3, Skovorody Str., Poltava, Ukraine \\ ${ }^{2}$ NSC "Institute of Agriculture", NAAS of Ukraine, 2-B, Mashynobudivnykiv Str., \\ Chabany village, Kyiv-Sviatoshyn District, Kyiv Region, Ukraine \\ ${ }^{3}$ National University of Life and Environmental Sciences of Ukraine, \\ 15, Heroes of Defense Str., Kyiv, Ukraine
}

E-mail:marenych@ukr.net,vzmm@naas.gov.ua,volodimirgangur@gmail.com, *2irinakorotkova10@gmail.com, taranenkoserg@ukr.net

Received March 15, 2020 / Received May 18, 2020 / Accepted July 20, 2020

\begin{abstract}
Aim. To study the impact of complex preparations, containing humic, fulvic and ulmic acids in combination with herbicides and nitrogen fertilizers, on winter wheat yield. Methods. Field, laboratory, statistical methods. Results. The impact of herbicides with different active substances and their mixtures with humic preparations Humifield and Foliar concentrate on weed infestation and productivity of Kryzhynka winter variety was investigated. It was determined that the application of herbicide Prima ( $400 \mathrm{~g} / \mathrm{ha})$ and the mixture of preparations Triger $(25 \mathrm{~g} / \mathrm{ha})+$ Tomigan $(0.5 \mathrm{l} / \mathrm{ha})$ in combination with humic preparation Humifield in the dose of $200 \mathrm{~g} /$ ha had practically no impact on the crop productivity. A considerable increase in the yield, for instance, by 15.6-20.3\%, was observed in case of spraying the fields with the same preparation forms of herbicides in the tank mixture with humic stimulator $4 \mathrm{R}$ Foliar concentrate in the dose of $2.0 \mathrm{~kg} / \mathrm{ha}$. The application of humates in combination with nitrogen fertilizers with the purpose of optimizing the nutrition system for winter wheat via their introduction superficially and by spraying the leaf-stem mass of plants was studied. It was demonstrated that the application of the growth regulator 5R SoilBoost in the amount of $11 \mathrm{~kg} / \mathrm{ha}$ in the mixture with $200 \mathrm{~kg} / \mathrm{ha}$ of ammonia nitrate led to the increase of productivity for Smuhlianka and Slavna varieties by 11.2 and $8.5 \%$ respectively, and double foliar application of $4 \mathrm{R}$ Foliar concentrate $(2+2 \mathrm{~kg} / \mathrm{ha})$ in the mixture with ammonia nitrate - by $15.5 \%$. The maximal increase in productivity by $20-23 \%$ was obtained after combined application of humic stimulators $5 \mathrm{R}$ SoilBoost $(11 \mathrm{~kg} / \mathrm{ha})$ and $4 \mathrm{R}$ Foliar concentrate $(2+2 \mathrm{~kg} / \mathrm{ha})$ on the background of ammonia nitrate ( $200 \mathrm{~kg} / \mathrm{ha}$ of physical weight). The efficiency of foliar fertilization for wheat fields of Kubus and Mulan varieties using the mixtures of humates and carbamide-ammonia mixture in different phases of crop development was analyzed. The application of such combinations also promoted the productivity increase by $10.0-21.4 \%$. Conclusions. The increase in productivity of Kryzhynka winter wheat variety by $0.64-0.84 \mathrm{t} / \mathrm{ha}$ was determined after spraying crop fields with the tank mixture of herbicides and humic stimulator 4R Foliar concentrate in the dose of $2.0 \mathrm{~kg} / \mathrm{ha}$. The efficiency of optimizing the nutrition system of plants via separate or combined application of humic preparations, in particular, granulated 5R SoilBoost $(11 \mathrm{~kg} / \mathrm{ha})$, superficially, and 4R Foliar concentrate $(2 \mathrm{~kg} / \mathrm{ha}+2 \mathrm{~kg} /$ ha) in case of foliar fertilization for fields in different phases of crop development on the background of early spring introduction of ammonia nitrate $(200 \mathrm{~kg} / \mathrm{ha})$ to frozen-thawed soil was proven. The increase in wheat productivity was observed in all variants of applying these mixtures. However, the maximal increase in the winter wheat yield was obtained due to the fertilization technology, envisaging the use of humates 5R SoilBoost and 4R Foliar concentrate on the background of ammonia nitrate. There was a noted increase in grain productivity of winter wheat varieties Kubus and Mulan by $0.50-0.94$ and $0.41-1.08 \mathrm{t} /$ ha respectively in case of superficial introduction of humic preparation $5 \mathrm{R}$ SoilBoost $(11 \mathrm{~kg} / \mathrm{ha})$ and foliar fertilization of wheat fields with 4R Foliar concentrate $(2+2 \mathrm{~kg} / \mathrm{ha})$ in combination with carbamide-ammonia mixture $(200+100 \mathrm{~kg} / \mathrm{ha})$.
\end{abstract}

Key words: humic acids, yield, herbicides, nitrogen fertilizers, plant nutrition system.

DOI:

(C) M. M. MARENYCH, V. F. KAMINSKY, C. Yu. BULYGIN, V. V. HANHUR, I. V. KOROTKOVA, S. O. YURCHENKO, A. V. BAHAN, S. V. TARANENKO, V. V. LIASHENKO, 2020 


\section{INTRODUCTION}

The search for efficient and economically reasonable method of managing the yield of agricultural crops envisages the application of a wide range of growth regulators, among which great attention is recently paid to humic preparations. The application of growth regulators of plants of predominantly humic origin is a mandatory way of intensive technologies, allowing for maximal realization of genetic potential of plant productivity (Trevisan S et al., 2010; Shah ZH et al., 2018; Ekin Z, 2019).

However, the impact of these substances is limited by the possibilities of the genotype of plants. It has been determined that they only help a plant to better realize its inherited potential which in some specific conditions has been still unrealized. The combined use of humates, containing complexes of humic and fulvic acids with the solutions of nutrients $(\mathrm{N}, \mathrm{P}, \mathrm{K}, \mathrm{Ca}, \mathrm{Mg}, \mathrm{S}, \mathrm{B}$, $\mathrm{Mo}, \mathrm{Cu}, \mathrm{Mn}, \mathrm{Fe}, \mathrm{Zn}$ ), leads to the stimulation of growth of both mono- and dicotyledonous plants, intensive accumulation of photosynthetic pigments, which has a positive impact on the yield of crops in future (Chen $Y$ et al, 2004).

One of the main sources of humic substances penetrating soil is the introduction of vermicompost and organo-mineral fertilizers. In addition to the stimulating impact on the yield, there is also their positive effect on mechanical and physico-chemical properties of soil (Turgay OC et al., 2011; Ihsanullah D, 2013; Rose MT et al., 2014; Bottinellia N et al., 2017; Sarma B et al., 2017).

Due to this fact, the role of humic preparations in enhancing fertility traits of soil at limited application of organic fertilizers, in particular, manure, is increasing (Dincsoy M, Sonmez F, 2019).

Humic acids are capable of demonstrating their antistress effect on plants at unfavorable soil and weather conditions of their cultivation (Jamal Y et al., 2011; Jarošová M et al., 2016).

The application of humic fertilizers decreases saline stress of plants, stimulates the development of beneficial microflora, which may result in the increase in wheat yield by $45.1-60.2 \%$ (Karcauskiene D et al., 2019; Liu ML et al., 2019).

Foliar application of humic substances, including fulvic acids, also had a favorable effect on plants, especially in drought conditions. It was demonstrated (Muhammad S et al., 2013; Zhang X et al., 2016) that foliar application of fulvic acid in combination with the ab- scisic acid promoted the decrease in moisture transpiration by wheat plants, their better adaptation to water stress conditions and ensured the increase in crop yield by $7-18 \%$ compared to the control. It was also determined that the adaptation of plants mainly occurred due to the permeability of pores and better balance of the upper and root masses.

The main ways of using preparations of humic substances during the cultivation of cereals is their introduction into soil, pre-sowing treatment of seeds and foliar fertilization. Any of these ways has a positive effect but the best result is achieved if they are applied in a complex. Pre-sowing treatment of seeds with humates accelerates its germination, enhances the development of the root system which activates the formation of vegetative mass. The application of humic acids optimizes the processes of seed germination under saline stress conditions. Positive results under such conditions were obtained for barley and wheat. It was determined that humic acids decreased the penetration of potassium into plants at its increased concentration in soil. The physiological impact of humic substances is also manifested in the optimization of osmotic processes and regulation of the content of photosynthetic pigments in young plants (Delfine S et al., 2005; Kandil AA et al., 2016; Qin Y et al., 2016; Ahmad T et al., 2018; Bezuglova OS et al., 2019).

However, foliar application of humic substances may not have a direct evident impact on the yield, but still have its positive effect on grain quality, and optimize the intake of macro- and microelements (Chen Y et al., 2004; Rodrigues LFOS et al., 2014; Akhtar K et al., 2015; Knapowski T et al., 2015; Shazma A et al., 2016).

A considerable number of treatments and related expenses for the application of humic substances may become a serious limiting factor for their wide application in some soil and climatic conditions since these preparations cannot decrease nutritious disbalance at the absence of required nutrients (Ibrahim OM et al., 2016).

The application of tank mixtures of herbicides and biostimulators may be a reasonable way of reducing expenses. The studies demonstrate that such combination has no considerable impact on phytotoxicity of herbicides and the amount of weeds, but there is an increase in the yield of oats and winter wheat (Soltani N et al., 2015; Matysiak K et al., 2018).

It should be noted that the problematics of using the preparations of humic acids is too contradictory and is 
yet to be solved. There are also scarce literature sources about the efficiency of using tank mixtures of herbicides and humates, due to which there is an increase in the urgency of studies on the application of humic preparations in the system of nutrition and protection of fields from weeds in the technology of cultivating winter wheat. Thus, our work was aimed at investigating the impact of complex preparations, containing humic, fulvic and ulmic acids in combination with herbicides and different forms of nitrogen fertilizers on the yield of winter wheat in the Forest-Steppe zone.

\section{MATERIALS AND METHODS}

The field experiment was conducted in 2014-2018 at the experimental field of the Poltava State Agrarian Academy (Ukraine) using five varieties of winter wheat: Kryzhynka, Smuhlianka, Slavna - originated from the V.M. Remeslo Myronivka Institute of Wheat, NAAS and the Institute of Plant Physiology and Genetics, NAS of Ukraine; Kubus - originated from KWS SAAT SE, Mulan - from Saaten Union. All the varieties are recommended for cultivation in the ForestSteppe zone of Ukraine.

In general, the years of studies were sufficiently favorable for the formation of winter wheat yield. However, the limiting factors, inhibiting the growth and development of wheat plants in 2015, were moisture deficiency during the last decade of March and regular ground frost. In 2016 moisture shortage was noted in June, and in 2017 - during the period of optimal sowing terms. Productive precipitation of the second half of October 2017 ensured obtaining complete germination, but the fields stopped autumn vegetation in the phase of 2-3 leaves. During winter no sharp deviations in air temperature were observed compared to average perennial values which ensured high survival rate of wheat plants till the time of renewed vegetation.

The soil of the experimental plot in the first experiment was typical chernozem, characterized by the following agrochemical indices: nitrogen content which was easily hydrolyzed - 33-74 mg (according to Turin and Kononova), phosphorus - 78-106 mg (according to Chirikov), potassium - 70-150 mg per one $\mathrm{kg}$ of soil (according to Maslova); in the second experiment - deep low-humus chernozem: humus content (according to Turin in the modification of Semakov) in the soil layer $(0-20 \mathrm{~cm})$ was $3.07-3.63 \%$. With deeper profile, the humus content decreased and at the depth of $40-50 \mathrm{~cm}$ amounted to $1.76-1.84 \%$, and at the depth of 80-09 cm - 1.06-1.15\%. The content of mobile phosphorus (according to Chirikov) - 80-90 $\mathrm{mg}$ and exchange potassium (according to Maslova) $100-110 \mathrm{mg}$ per one $\mathrm{kg}$ of soil. In the third experiment, the soil of the experimental plot was residually weakly saline poorly eroded chernozem. The humus content was 3.1-4.1\%, easily hydrolyzed nitrogen (according to Turin and Kononova) - 101-151 mg/kg of soil, phosphorus (according to Chirikov) - 120-140 mg, potassium (according to Maslova) - 85-130 mg per one $\mathrm{kg}$ of soil. The experiments were repeated three times, the variants were randomly located. The area of the plot for sowing and the area under registration was 0.32 ha. Soybeans were the predecessor in the first two experiments, and peas - in the third one. The crop was sown using Horsch Pronto 6AS sowing machine. The efficiency of herbicides was estimated by counting the number of weeds per one square meter of the field 14 days after spraying for each variant according to the method of testing pesticides (Rozhkov AO et al., 2016).

Table 1. Investigated herbicides and growth regulators

\begin{tabular}{|c|c|c|}
\hline Name & Active substance & $\begin{array}{l}\text { Concentration of active } \\
\text { substance }\end{array}$ \\
\hline Granstar Pro & tribenuron methyl & $750 \mathrm{~g} \mathrm{~kg}^{-1}$ \\
\hline Grodil Maxi & iodosulfuron + amidosulfuron + mefenpyr-diethyl (antidote) & $25 \mathrm{~g} \mathrm{l}^{-1}+100 \mathrm{~g} \mathrm{l}^{-1}+250 \mathrm{~g} \mathrm{l}^{-1}$ \\
\hline Prima & florasulam + 2-ethylhexyl ester 2.4-D & $6.25 \mathrm{~g} \mathrm{l}^{-1}+452.5 \mathrm{~g} \mathrm{l}^{-1}$ \\
\hline Triger & tribenuron methyl & $500 \mathrm{~g} \mathrm{~kg}^{-1}$ \\
\hline Tomigan & fluroxypyr & $250 \mathrm{~g} \mathrm{l}^{-1}$ \\
\hline Humifield & potassium humate & $560-720 \mathrm{~g} \mathrm{~kg}^{-1}$ \\
\hline 4R Foliar concentrate & Humic acids + fulvic acids + ulmic acids + microelements & $550+210+50+60 \mathrm{~g} \mathrm{l}^{-1}$ \\
\hline 5R SoilBoost & Humic acids + fulvic acids + ulmic acids + microelements & $590+200+50+60 \mathrm{~g} \mathrm{l}^{-1}$ \\
\hline
\end{tabular}

Note: $1-5$-herbicides; 6,7 - humic preparations. 
The weight of 1,000 grains was determined according to (Ol'hovs'kyj GF et al, 2019). The productive tillering and weight of grain from one spikelet was determined by the Method of conducting the expert evaluation of plant varieties from the group of grains, cereals, and grain legumes for their suitability to dissemination in Ukraine (Livandovskyi AA et al., 2016).

The yield was registered by the method of direct combining from each plot. The cultivation of wheat involved the use of herbicides and growth regulators based on humic preparations, presented in Table 1.

The studies of the crop yield depending on the system of introducing fertilizers and growth stimulators were conducted in three experiments, each of them containing several variants.

Kryzhynka winter wheat variety was sown in the first experiment. The scheme of the experiment envisaged the variants of using pure herbicides and the tank mixture with humic preparations Humifield (Humintech, Germany) and 4R Foliar concentrate (SoilBiotics, the USA) (Table 2).

Smuhlianka and Slavna winter wheat varieties were used in the second experiment to study the impact of combinations of nitrogen fertilizers and humic preparations 5R SoilBoost and 4R Foliar concentrate. Ammonium nitrate (in the granulated form) and 5R SoilBoost were introduced superficially, foliar fertilization of plants was done with 4R Foliar concentrate in the tillering phase (BBCH 23-28) and in the phase of spikelet formation (BBCH 51-55). The scheme of the experiment is presented in Table 3.

Kubus and Mulan winter wheat varieties were used in the third experiment. The study envisaged double foliar application of the carbamide-ammonia mixture (CAM) in a pure form during the tillering phase and the phase of stem elongation (variant 1) and in the form of a mixture with the humic preparation $4 \mathrm{R}$ Foliar concentrate (variants 3,4 ). In variant 2 the mentioned fertilizers were introduced in a pure form consistently, as indicated in Table 4 (5R SoilBoost was applied superficially).

The statistical processing of the data was conducted by the methods of descriptive statistics, regression and dispersion analysis using StatSoft Statistica (version 10.0). The significance of experimental data was evaluated using the dispersion analysis (ANOVA) after calculating the least significant difference $L S D_{0 .}$.

Table 2. The impact of herbicides and their mixtures on weed infestation and yield of Kryzhynka winter wheat variety

\begin{tabular}{|c|c|c|c|c|c|}
\hline \multirow{3}{*}{ Experiment variants } & \multirow{3}{*}{ Doses } & \multicolumn{3}{|c|}{$\begin{array}{c}\text { Weed infestation } 14 \text { days after } \\
\text { spraying }\end{array}$} & \multirow{3}{*}{$\begin{array}{l}\text { Yield, } \\
\text { tons/ha }\end{array}$} \\
\hline & & \multicolumn{2}{|c|}{$\begin{array}{l}\text { Number of weeds, } \\
\text { plants/sq.m. }\end{array}$} & \multirow{2}{*}{$\begin{array}{l}\text { air-dry } \\
\text { mass, } \\
\text { g/sq.m. }\end{array}$} & \\
\hline & & total & $\begin{array}{l}\text { incl. } \\
\text { perennial }\end{array}$ & & \\
\hline Granstar Pro & $20 \mathrm{~g} \mathrm{ha}^{-1}$ & 41.87 & 2.21 & 4.93 & 4.28 \\
\hline Grodil Maxi & $100 \mathrm{~g} \mathrm{ha}^{-1}$ & 43.66 & 2.43 & 5.21 & 4.28 \\
\hline Prima & $400 \mathrm{~g} \mathrm{ha}^{-1}$ & 39.83 & 2.24 & 5.05 & 4.14 \\
\hline Triger + Tomigan & $25 \mathrm{~g} \mathrm{ha}^{-1}+0.51 \mathrm{ha}^{-} 1$ & 36.92 & 2.12 & 5.79 & 4.30 \\
\hline Granstar Pro + Humifield & $20 \mathrm{~g} \mathrm{ha}^{-1}+200 \mathrm{~g} \mathrm{ha}^{-1}$ & 41.87 & 2.11 & 5.61 & 4.19 \\
\hline Grodil Maxi + Humifield & $100 \mathrm{~g} \mathrm{ha}^{-1}+200 \mathrm{~g} \mathrm{ha}^{-1}$ & 35.33 & 1.96 & 4.96 & 4.43 \\
\hline Prima + Humifield & $400 \mathrm{~g} \mathrm{ha}^{-1}+200 \mathrm{~g} \mathrm{ha}^{-1}$ & 37.11 & 2.03 & 4.84 & 4.22 \\
\hline Triger + Tomigan + Humifield & $25 \mathrm{~g} \mathrm{ha}^{-1}+0.51 \mathrm{ha}^{-1}+200 \mathrm{~g} \mathrm{ha}^{-1}$ & 39.77 & 2.13 & 5.51 & 4.30 \\
\hline Granstar Pro + 4R Foliar concentrate & $20 \mathrm{~g} \mathrm{ha}^{-1}+2 \mathrm{~kg} \mathrm{ha}^{-1}$ & 48.00 & 2.91 & 6.76 & 4.92 \\
\hline Grodil Maxi $+4 \mathrm{R}$ Foliar concentrate & $100 \mathrm{~g} \mathrm{ha}^{-1}+2 \mathrm{~kg} \mathrm{ha}^{-1}$ & 55.83 & 2.82 & 5.44 & 4.92 \\
\hline Prima + 4R Foliar concentrate & $400 \mathrm{~g} \mathrm{ha}^{-1}+2 \mathrm{~kg} \mathrm{ha}^{-1}$ & 53.00 & 3.18 & 6.47 & 4.98 \\
\hline Triger + Tomigan $+4 \mathrm{R}$ Foliar concentrate & $25 \mathrm{~g} \mathrm{ha}^{-1}+0.51 \mathrm{ha}^{-1}+2 \mathrm{~kg} \mathrm{ha}^{-1}$ & 52.77 & 3.13 & 6.37 & 4.97 \\
\hline \multicolumn{2}{|l|}{$L S D_{05}$} & 11.2 & 0.58 & 1.29 & 0.34 \\
\hline
\end{tabular}




\section{RESULTS OF INVESTIGATIONS}

The data of experiment 1 were used to analyze the impact of herbicides with different active substances (variants 1-4) and their mixtures with humic preparations Humifield (variants 5-8) and 4R Foliar concentrate (variants 9-12) on the total number of weeds in the field of Kryzhynka wheat variety and thus on the crop yield (Table 2).

The results obtained demonstrated that herbicides under investigation and their mixtures had similar suppressive effect on weeds survival rate.

It is known that humates promote better and faster penetration of the active substance of herbicide into weeds, intensifying the exchange processes in plants, which accelerates their destruction (Soroka TA et al, 2012).

We studied different variants of composing the mixtures of herbicides with humic growth stimulators to enhance the efficiency of their action. The addition of a humic preparation Humifield (200 $\left.\mathrm{g} \mathrm{ha}^{-1}\right)$ to herbicides Granstar Pro, Prima, Grodil Maxi and Triger + Tomigan did not have a significant effect on the number of weeds in the fields of winter wheat (Table 2).

The total inhibiting action of the mixture of herbicides and Humifield should be noted. On the contrary, their application in the mixture with 4R Foliar concentrate had a stimulating effect. For instance, prior to the time of harvesting, the number of weeds increased in the areas of the field, treated with the mixture of $4 \mathrm{R}$ Foliar concentrate with any herbicide: Grodil Maxi, Prima or (Triger + Tomigan). The most significant reliable increase in the number of weeds was observed in case of using mixtures (Prima $+4 \mathrm{R}$ Foliar concentrate) and (Triger + Tomigan $+4 \mathrm{R}$ Foliar concentrate) - by 33 and $43 \%$ respectively.

The experimental data of Table 2 demonstrate that in variants with application of herbicides in pure form, the yield of winter wheat was from 14 to $4.30 \mathrm{t} / \mathrm{ha}$, and the difference between them was not significant. The analysis of the correlation $(r=0.423)$ between the number of weeds and the yield demonstrated that the best variant was the combined application of herbicides Triger + Tomigan (variant 4), leading to. the smallest number of weeds (36.92 plants/sq.m.), and the highest grain productivity of the crop $(4.3 \mathrm{t} / \mathrm{ha})$.

However, this correlation was not regular for all the other variants of applying herbicides. The results of the studies demonstrated that the application of herbicides (regardless of their kind and amount of active substances and the preparation form) in combination with Humifield did not impact the yield of Kryzhynka

Table 3. The impact of fertilization variants on the yield of winter wheat varieties Smuhlianka and Slavna

\begin{tabular}{|c|c|c|c|c|c|}
\hline Experiment variants & Doses & PT & $\begin{array}{l}\text { Weight of } \\
\text { grain from } \\
\text { one spikelet, } \\
\text { g }\end{array}$ & $\begin{array}{l}\text { Weight } \\
\text { of thousand } \\
\text { grains, g }\end{array}$ & Yield, t/ha \\
\hline \multicolumn{6}{|c|}{ Smuhlianka/Slavna } \\
\hline $\begin{array}{l}\text { Ammonia nitrate } \\
\text { (control) }\end{array}$ & $200 \mathrm{~kg} / \mathrm{ha}$ & $1.59 / 1.46$ & $1.61 / 1.51$ & $42.11 / 41.31$ & $5.17 / 4.95$ \\
\hline $\begin{array}{l}\text { Ammonia nitrate } \\
+5 \mathrm{R} \text { SoilBoost }\end{array}$ & $200 \mathrm{~kg} / \mathrm{ha}+11 \mathrm{~kg} / \mathrm{ha}$ & $1.72 / 1.66$ & $1.72 / 1.64$ & $42.77 / 41.75$ & $5.75 / 5.37$ \\
\hline $\begin{array}{l}\text { Ammonia nitrate } \\
+4 \mathrm{R} \text { Foliar concentrate }+4 \mathrm{R} \\
\text { Foliar concentrate }\end{array}$ & $\begin{array}{l}200 \mathrm{~kg} / \mathrm{ha} \\
+2 \mathrm{~kg} / \mathrm{ha} \\
+2 \mathrm{~kg} / \mathrm{ha}\end{array}$ & $1.69 / 1.66$ & $1.82 / 1.64$ & $42.73 / 41.62$ & $5.97 / 5.87$ \\
\hline $\begin{array}{l}\text { Ammonia nitrate } \\
+5 \mathrm{R} \text { SoilBoost } \\
+4 \mathrm{R} \text { Foliar concentrate } \\
+4 \mathrm{R} \text { Foliar concentrate }\end{array}$ & $\begin{array}{l}200 \mathrm{~kg} / \mathrm{ha} \\
+11 \mathrm{~kg} / \mathrm{ha} \\
+2 \mathrm{~kg} / \mathrm{ha} \\
+2 \mathrm{~kg} / \mathrm{ha}\end{array}$ & $1.78 / 1.75$ & $1.84 / 1.77$ & $43.25 / 42.19$ & $6.32 / 6.10$ \\
\hline \multicolumn{2}{|l|}{$L S D_{05}$} & 0.13 & 0.07 & 0.67 & 0.28 \\
\hline
\end{tabular}

Note. PT - productive tillering, stems/plants. 
winter wheat variety on statistically reliable level. At the same time, a considerable increase in the yield was observed in the areas of the field, treated with the mixtures of herbicides and humic preparation 4R Foliar concentrate in the dose of $2.0 \mathrm{~kg} / \mathrm{ha}$ (variants 9-12). Although the yield in these variants had almost no differences (4.92-4.98 t/ha), it exceeded the same index in the areas, treated with pure herbicides (4.14$-4.30 \mathrm{t} / \mathrm{ha}$ ) considerably. The highest gain in the yield of $20.3 \%$ was obtained when treating winter wheat fields with the mixture (Prima $+4 \mathrm{R}$ Foliar concentrate), regardless of the highest number of weeds (53.00 plants/sq.m., including perennial weeds, 3.18 plants/sq.m.) in this area of the field.

Therefore, it would be unreasonable to recommend using combined application of herbicides and the humic preparation 4R Foliar concentrate or decreasing the norms of applying herbicides.

The application of humates for the optimization of the nutrition system via superficial introduction of nutrients and spraying the leaf-stem mass of plants was studied in experiment 2 using wheat varieties Smuhlianka and Slavna (Table 3). Only ammonia nitrate in the norm of $200 \mathrm{~kg} / \mathrm{ha}$ was introduced in the control plot.

The presented data demonstrated that the application of granulated growth regulator 5R SoilBoost in the amount of $11 \mathrm{~kg} / \mathrm{ha}$ in the mixture with $200 \mathrm{~kg}$ / ha of ammonia nitrate allowed increasing the yield of Smuhlianka variety by $11.2 \%$. Double foliar application of $4 \mathrm{R}$ Foliar concentrate $(2+2 \mathrm{~kg} / \mathrm{ha})$ on the background of introducing ammonia nitrate promoted the increase in the yield of Smuhlianka wheat variety by $15.5 \%$ (variant 3 ). The highest gain in the yield of $22.2 \%$ was obtained after foliar fertilization of the fields with 4R Foliar concentrate which was introduced twice in the tillering phase in the dose of $2 \mathrm{~kg} / \mathrm{ha}$ on the background of the introduction of the mixture of ammonia nitrate and 5R SoilBoost in the phase of emerging spikelets (variant 4).

A similar regularity was also observed in the experimental variants with Slavna wheat variety. The fertilization system, presented in variant 4 , was found to be the most efficient: the yield of Slavna wheat variety increased by $23.2 \%$ compared to the control ( $4.95 \mathrm{t} / \mathrm{ha})$.

Rather high impact on the yield of Kubus and Mulan wheat varieties was demonstrated by complexes of humic preparations 5R SoilBoost and 4R Foliar concentrate with liquid carbamide-ammonia mixture (CAM) which served as the background in experiment 3 .

Different compositions of CAM with humic preparations, which were introduced foliarly, led to the increase in the yield of both wheat varieties on statistically significant level (Table 4). For instance, in case of superficial fertilization on frozen-thawed soil using $5 \mathrm{R}$ SoilBoost preparation $(11 \mathrm{~kg} / \mathrm{ha})$, the yield of Kubus

Table 4. The yield of Kubus and Mulan winter wheat varieties depending on the fertilization variant

\begin{tabular}{|c|c|c|c|c|c|}
\hline Experiment variants & Doses & PT & $\begin{array}{l}\text { Weight } \\
\text { of grain } \\
\text { from one } \\
\text { spikelet, g }\end{array}$ & $\begin{array}{l}\text { Weight } \\
\text { of thousand } \\
\text { grains, } g\end{array}$ & Yield, t/ha \\
\hline \multicolumn{6}{|c|}{ Kubus/Mulan } \\
\hline CAM (background) + CAM & $\begin{array}{l}200 \mathrm{~kg} / \mathrm{ha} \\
+100 \mathrm{~kg} / \mathrm{ha}\end{array}$ & $1.50 / 1.57$ & $1.61 / 1.65$ & $41.84 / 41.95$ & $4.99 / 5.04$ \\
\hline 5R SoilBoost + CAM + CAM & $\begin{array}{l}11 \mathrm{~kg} / \mathrm{ha} \\
+200 \mathrm{~kg} / \mathrm{ha}+100 \mathrm{~kg} / \mathrm{ha}\end{array}$ & $1.61 / 1.66$ & $1.68 / 1.73$ & $41.98 / 41.89$ & $5.49 / 5.45$ \\
\hline $\begin{array}{l}(\mathrm{CAM}+4 \mathrm{R} \text { Foliar concentrate })+ \\
(\mathrm{CAM}+4 \mathrm{R} \text { Foliar concentrate })\end{array}$ & $\begin{array}{l}(200 \mathrm{~kg} / \mathrm{ha} \\
+2 \mathrm{~kg} / \mathrm{ha}) \\
+(100 \mathrm{~kg} / \mathrm{ha}+2 \mathrm{~kg} / \mathrm{ha})\end{array}$ & $1.70 / 1.68$ & $1.74 / 1.76$ & $42.24 / 41.89$ & $5.75 / 5.77$ \\
\hline $\begin{array}{l}\text { 5R SoilBoost }+(\text { CAM }+4 R \text { Foliar } \\
\text { concentrate })+(\text { CAM }+4 R \text { Foliar } \\
\text { concentrate })\end{array}$ & $\begin{array}{l}11 \mathrm{~kg} / \mathrm{ha} \\
+(200 \mathrm{~kg} / \mathrm{ha}+2 \mathrm{~kg} / \mathrm{ha}) \\
+(100 \mathrm{~kg} / \mathrm{ha}+2 \mathrm{~kg} / \mathrm{ha})\end{array}$ & $1.76 / 1.69$ & $1.80 / 1.77$ & $42.55 / 42.35$ & $5.93 / 6.12$ \\
\hline \multicolumn{2}{|l|}{$L S D_{05}$} & 0.13 & 0.07 & 0.67 & 0.28 \\
\hline
\end{tabular}




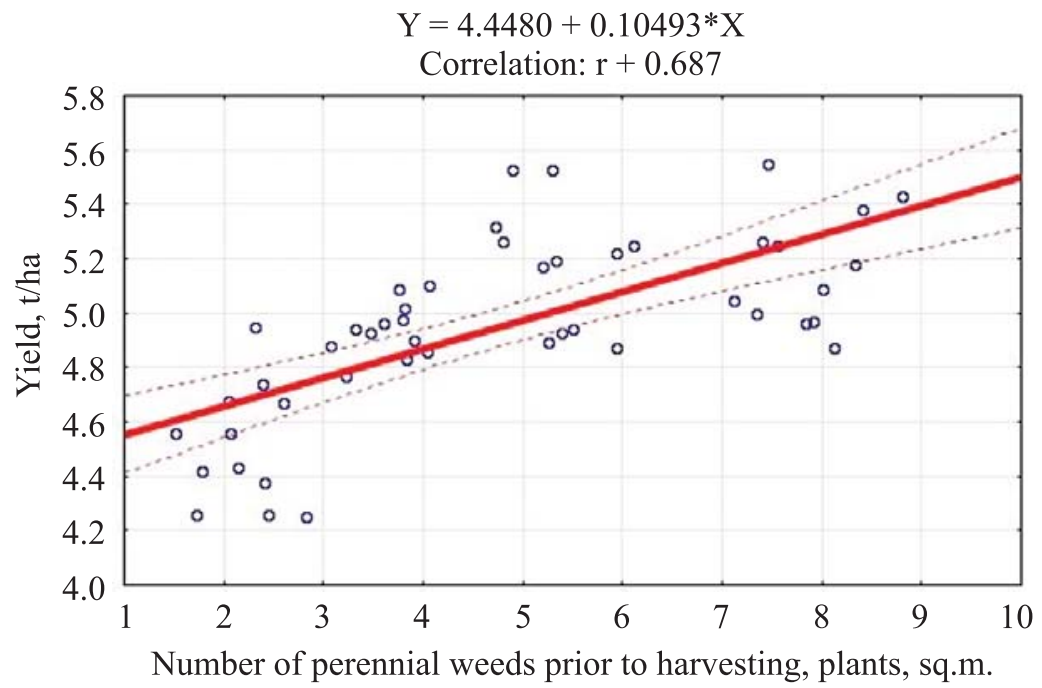

Fig. 1. The chart of linear regression for weed infestation and yield in case of using the tank mixture of herbicides and $4 R$ Foliar concentrate

winter wheat variety increased by $10 \%$, and that of Mulan - by $8.1 \%$ (variant 2) compared to the background (CAM). Foliar fertilization of wheat fields with the humic preparation $4 \mathrm{R}$ Foliar concentrate in the mixture with CAM in the phase of tillering and in the phase of emerging spikelets $(2 \mathrm{~kg} / \mathrm{ha})$ allowed increasing the yield of Kubus and Mulan varieties by 15.2 and $14.5 \%$ respectively.

The highest increase in the yield of Kubus and $\mathrm{Mu}-$ lan wheat varieties (18.8 and $21.4 \%$ respectively) was ensured by the combined introduction of soil activator 5R SoilBoost $(11 \mathrm{~kg} / \mathrm{ha})$ and double foliar fertilization with humate $4 \mathrm{R}$ Foliar concentrate in the combination with liquid nitrogen fertilizer CAM.

It is known that a key component of wheat yield is productive tillering (PT) which is defined as a number of stems, forming spikelets and grain. Productive tillering is a trait, which shows the greatest response to the cultivation factors. The results of disperse analysis demonstrated that the main factor, impacting the formation of the number of stems in Smuhlianka and Slavna wheat varieties, were varietal specificities - $49.9 \%$, a share of the impact from the nutrition method was $32.1 \%$ in the total dispersion of the trait, and meteorological conditions had not more than $5 \%$ of the impact. The impact of all the factors on productive tillering equaled $2-5 \%$ from the dispersion of the trait. This index demonstrated rather high efficiency of cultivation technologies due to selection of varieties and agrotechnical measures.

Kubus and Mulan wheat varieties were found to be more dependent on weather conditions. The share of their impact on the yield amounted to almost $61 \%$ and on the fertilization variant $-22 \%$. The varieties did not differ in productive tillering.

\section{DISCUSSION OF STUDY FINDINGS}

The application of herbicides and their tank mixtures with humic stimulators changes the regularities of combined existence of agrocenosis components considerably. First of all, it relates to the character of correlations between the yield level and the number of weeds per square unit. In the experiment variants, where herbicides were used in pure form and in the tank mixture with Humifield, correlations between these indices were absent. However, in the variants where 4R Foliar concentrate was a component of the tank mixture, direct correlation was observed with strong relationship between the number of perennial weeds and the yield of winter wheat (Fig. 1). It demonstrated that humic preparation 4R Foliar concentrate in the tank mixture with herbicides enhanced the resistance of weeds to the destructive action of herbicides, thus, the number of weeds in winter wheat fields decreased without negative impact on the yield of the crop.

To specify the determined regularity, the study results were processed by the method of non-linear evaluation. The dependence of parabolic type was determined for this experiment which demonstrated not only positive impact of the growth stimulator on the yield of winter wheat, but also on the increase in survival rate of weeds due to the phytotoxic action of herbicides (Fig. 2). Theoretically, the number of perennial weeds of 6-7 plants/ 


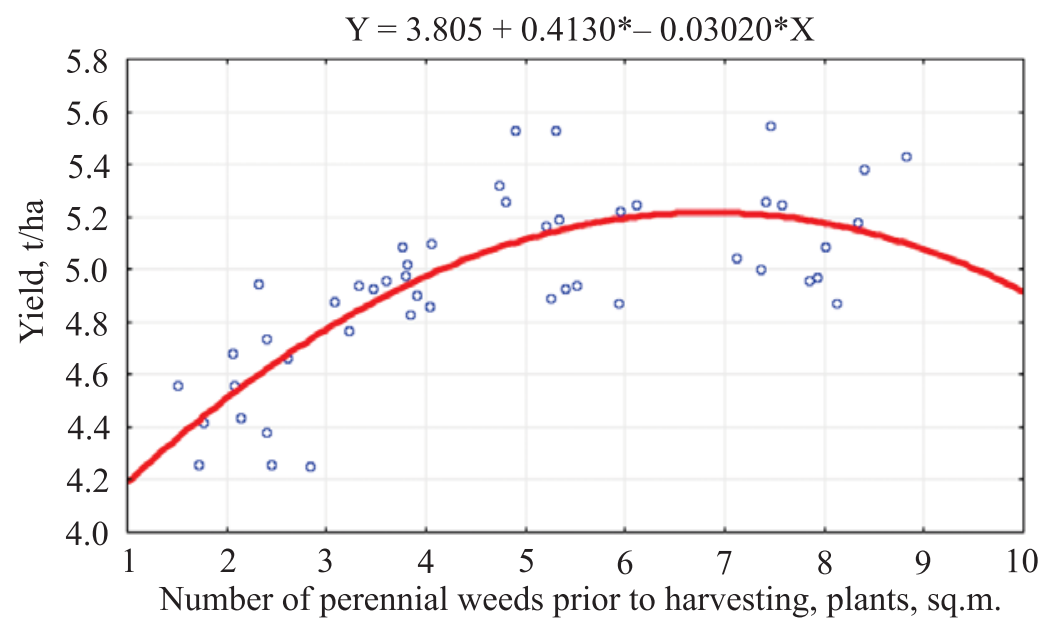

Fig. 2. The chart of regression for weed infestation and yield in case of using the tank mixture of herbicides and 4R Foliar concentrate

sq.m. is acceptable from the standpoint of production, but further increase in their number would lead to the decrease in the yield.

Therefore, the results of our investigations are in agreement with the experimental data, presented in other scientific articles. For instance, it was shown that the use of sulfophenyl urea may induce chemical stress in wheat plants and decrease the number of bacteria in rhizosphere, and the application of humic stimulators allowed decreasing this negative effect considerably and increasing the yield by $22.5 \%$ (Bezuglova OS et al., 2019).

However, as shown in the article (Soltani N et al., 2015), the introduction of the stimulator Crop Booster to the tank mixture of herbicide with bromoxynil as the active substance did not demonstrate any considerable effect of the number of weeds in winter wheat fields.

Mineral fertilization of fields, including the application of nitrogen fertilizers, plays a relevant role as a technology of increasing the yield and improving winter wheat grain quality. It is possible to achieve rather high level of winter wheat yield using fertilization technologies which envisage the application of both granulated (usually ammonia nitrate) and liquid (CAM) nitrogen fertilizers in combination with humic stimulators.

It is known that carbamide ammonia mixture is a fertilizer with many advantages compared to solid nitrogen fertilizers. These advantages include: uniform introduction of fertilizers into soil and minimal loss of nutrients as well as the decrease in environment pollution. Contrary to ammonia nitrate, CAM can provide for prolonged nutrition of nitrogen for plants, as it con- tains its three forms: nitrate, ammonia and amide. Due to the activity of soil microorganisms, amide nitrogen transforms first into ammonium form and then into nitrate form. Due to the absence of free ammonia in the composition of CAM, it does not evaporate into air after its introduction into soil (Dudkyna E, 2013; Zhelyazkov OI, 2015).

The studies demonstrated positive impact of the combined application of different forms of nitrogen fertilizers and humic preparations on the productivity elements of winter wheat varieties under investigation. The weight of grain from one spikelet is a relevant index of yield structure.

It is known that the level of mineral nutrition for plants, weather conditions, varietal specificities of the cultivated crops are important regulating factors in the process of forming the weight of grain from one spikelet. The results of dispersion analysis in our studies demonstrated that weather conditions had the greatest impact on this index of grain quality. The share of their impact for winter varieties Slavna and Smuhlianka was $36 \%$, whereas for Kubus and Mulan varieties it was almost $70 \%$. Regardless of differences between wheat varieties under investigation in our work, the share of the impact of varietal traits was found to be practically equal and amounted to $32.5 \%$. There were no considerable differences in the impact of nutrition ways on the formation of the weight of grain from one spikelet, which was $26.1 \%$ for Slavna and Smuhlianka varieties and $20.5 \%$ for Kubus and Mulan. As seen from the data in Tables 3 and 4, the plants, cultivated in the plots, treated with the mixtures of mineral fertilizers with humic preparations, were characterized by higher 
indices of the weight of grain from one spikelet compared to control plots, where only nitrogen fertilizers were applied. The highest gain in the weight of grain from one spikelet of 14.3 and $17.2 \%$ after the introduction of these fertilization mixtures was obtained for Smuhlianka and Slavna varieties respectively. Kubus and Mulan varieties were found to be less sensitive for this variant of fertilization and this index amounted only to 11.8 and $7.3 \%$ respectively.

It should be noted that improving the indices of structure and yield quality, including the increase in the number of grains in the spikelet and their weight, higher content of proteins and fibers due to combined application of nitrogen fertilizers and humic stimulators was highlighted in several scientific articles Artyushenko AP, 2015; Gamayunova VV et al., 2018).

The article (Kandil AA et al., 2016) demonstrated that foliar application of humic acids increased biological yield of grain by $23.29 \%$, and protein content - by $10.98 \%$ compared to the control.

\section{CONCLUSIONS}

Therefore, the efficiency of treating winter wheat fields with herbicides and nitrogen fertilizers and their mixtures with growth regulators of humic origin, containing humic, fulvic and ulmic acids was proven and their impact on the yield was analyzed. Among the variants of the mixtures of herbicides and growth stimulators of humic origin, the most efficient ones were the mixtures with $4 \mathrm{R}$ Foliar concentrate $(2.0 \mathrm{~kg} / \mathrm{ha})$, the application of which promoted the increase in the crop yield by $16.5-20.3 \%$.

It was also determined that the treatment of the fields with the mixtures of nitrogen fertilizers with humic preparations promoted the increase in wheat grain yield in each variant. The use of the mixture of 5R SoilBoost in the dose of $11 \mathrm{~kg} / \mathrm{ha}$ and $200 \mathrm{~kg} / \mathrm{ha}$ of ammonia nitrate ensured the yield increase by $11.2 \%$, and double application of $4 \mathrm{R}$ Foliar concentrate $(2+2 \mathrm{~kg} / \mathrm{ha})$ in combination with ammonia nitrate - by $15.5 \%$. The increase in winter wheat yield, compared to the control, was the highest (20-23\%) in case of combined application of humic stimulators $5 \mathrm{R}$ SoilBoost and $4 \mathrm{R}$ Foliar concentrate on the background of ammonia nitrate.

High agronomic efficiency of applying humic compositions with carbamide-ammonia mixture was determined in different phases of plant development, where the amount of the additional yield of crop grain was $10.0-21.4 \%$.
Adherence to ethical principles. This article does not contain any results of studies, involving the use of animals as objects of study.

Conflict of interests. The authors deny any conflict of interests.

Financing. This study was not financed by any grants from financing institutions in the state, commercial or non-commercial sectors.

\section{Оптимізація чинників управління продукційними процесами пшениці озимої в зоні Лісостепу}

М. М. Маренич ${ }^{1}$, В. Ф. Камінський ${ }^{2}$, С. Ю. Булигін ${ }^{3}$, В. В. Гангур ${ }^{1}$, I. В. Короткова ${ }^{1 *}$, С. О. Юрченко ${ }^{1}$, А. В. Баган ${ }^{1}$, С. В. Тараненко ${ }^{1}$, В. В. Ляшенко ${ }^{1}$

${ }^{1}$ Полтавська державна аграрна академія, вул. Сковороди, 1/3, Полтава, Україна

${ }^{2}$ ННЦ “Інститут землеробства” НААН України, вул. Машинобудівників, 2-Б,

смт. Чабани, Києво-Святошинський район, Київська область, Україна

${ }^{3}$ Національний університет біоресурсів і природокористування України, 03041, Україна, Київ, вул. Героїв Оборони, 15

e-mail:marenych@ukr.net,vzmm@naas.gov.ua, volodimirgangur@gmail.com,

*2irinakorotkova10@gmail.com,

Yurchenko-svetlana@ukr.net, allabagan@ukr.net, taranenkoserg@ukr.net, viktor.liashenko@ukr.net

Мета. Вивчити вплив застосування комплексних препаратів, що містять гумінові, фульвові i ульмінові кислоти в поєднанні з гербіцидами і азотними добривами, на урожайність пшениці озимої. Методи. Польовий, лабораторний, статистичний. Результати. Досліджено вплив гербіцидів з різними діючими речовинами та їх сумішок з гуміновими препаратами Humifield i Foliar concentrate на забур'яненість посівів та урожайність пшениці озимої сорту Крижинка. Встановлено, що використання гербіциду Пріма (400 г/га) та суміші препаратів Тригер (25 г/га) + Томіган $(0,5$ л/га) у поєднанні 3 гуміновим препаратом Humifield в нормі 200 г/га практично не вплинуло на рівень урожайності культури. Істотне збільшення урожайності, зокрема на 15,6$20,3 \%$, спостерігали за обприскування посівів такими ж препаративними формами гербіцидів у баковій суміші з гуміновим стимулятором 4R Foliar concentrate y дозі 2,0 кг/га. Вивчено застосування гуматів в суміші 3 азотними добривами для оптимізації системи живлення пшениці озимої шляхом їх внесення поверхневим способом та обприскування листково-стеблової маси рослин. Показано, що використання гранульованого регулятора росту 5R SoilBoost в кількості 11 кг/га в суміші $з 200$ кг/га аміачної селітри призводить до збільшення урожайності сортів Смуглянка і Славна на 11,2 
і 8,5 \% відповідно, а двократне позакореневе застосування 4R Foliar concentrate $(2+2$ кг/га) в суміші 3 аміачною селітрою - на $15,5 \%$. Максимальне збільшення урожайності на 20-23\% було отримане за сумісного використання гумінових стимуляторів $5 \mathrm{R}$ SoilBoost $(11 \kappa г / \Gamma a)$ i 4R Foliar concentrate $(2+2$ кг/га) на фоні аміачної селітри (200 кг/га фізичної ваги). Проаналізовано ефективність позакореневого підживлення посівів пшениці сортів Кубус і Мулан сумішами гуматів з карбамідно-аміачною сумішшю в різні фази розвитку культури. Використання таких композицій також сприяло підвищенню урожайності на 10,0-21,4 \%. Висновки. Встановлено збільшення урожайності пшениці озимої сорту Крижинка на 0,64-0,84 т/га за обприскування посівів культури баковою сумішшю гербіцидів та гумінового стимулятора 4R Foliar concentrate у дозі 2,0 кг/га. Доведено ефективність оптимізації системи живлення рослин шляхом окремого або поєднаного застосування гумінових препаратів, зокрема гранульованого 5R SoilBoost (11 кг/га) поверхневим способом та 4R Foliar concentrate $(2$ кг/га +2 кг/га) за позакореневого підживлення посівів у різні фази розвитку культури на фоні ранньовесняного внесення аміачної селітри (200 кг/га) по мерзлоталому грунту. Збільшення урожайності пшениці спостерігали в будьякому варіанті застосування таких сумішей. Однак максимальний приріст урожаю пшениці озимої було отримано за технології підживлення, яка передбачала використання гуматів 5R SoilBoost i 4R Foliar concentrate на фоні аміачної селітри. Відзначено зростання зернової продуктивності сортів пшениці озимої Кубус і Мулан, відповідно на 0,50-0,94 і 0,41-1,08 т/га за поверхневого внесення гуміного препарату 5R SoilBoost (11 кг/га) та позакореневого підживлення посівів пшениці 4R Foliar concentrate $(2$ кг/га +2 кг/га) у поєднанні 3 карбамідно-аміачною сумішшю $(200+100$ кг/га).

Ключові слова: гумінові кислоти, урожайність, гербіциди, азотні добрива, система живлення рослин.

\section{REFERENCES}

Ahmad T, Khan R, Khattak TN. (2018) Effect of humic acid and fulvic acid based liquid and foliar fertilizers on the yield of wheat crop. J. Plant Nutr. 41(19):2438-45. https://doi.org/10.1080/01904167.2018.1527932.

Akhtar K, Khan A, Jan MT et al. (2015) Effect of humic acid and crop residue application on emergence and wheat phenology. Pure Appl. Bio. 4(1):97-103.

Artyushenko AP (2015) Features of the photosynthetic activity of plants of winter wheat depending on the factors of intensification. Agrar. Bull. Black sea littoral. 76:9-13.

Bottinellia N, Angersb DA, Hallaire V et al. (2017) Tillage and fertilization practices affect soil aggregate stability in a Humic Cambisol of Northwest France. Soil Till Res. 170:14-7. https://doi.org/10.1016/j.still.2017.02.008.
Bezuglova OS, Gorovtsov AV, Polienko EA et al. (2019) Effect of humic preparation on winter wheat productivity and rhizosphere microbial community under herbicideinduced stress. J. Soils Sed. 19(6):2665-75. doi.org/ 10.1007/s11368-018-02240-z.

Chen Y, Clapp CE, Magen H. (2004) Mechanisms of plant growth stimulation by humic substances: The role of organo-iron complexes. Soil Sci. Plant Nutr. 50(7):108995. https://doi.org/10.1080/00380768.2004.10408579.

Dincsoy M, Sonmez F. (2019) The effect of potassium and humic acid applications on yield and nutrient contents of wheat (Triticum aestivum L. var. Delfii) with same soil properties. J. Plant Nutr. 42(20):2757-72. https://doi.org/ 10.1080/01904167.2019.1658777.

Delfine S, Tognetti R, Desiderio E et al. (2005) The effect of foliar application of $\mathrm{N}$ and humic acids on the growth and yield of durum wheat. Agron. Sustain. Dev. 25(2):18391. https://doi.org/10.1051/agro:2005017.

Dudkyna E. (2013) Carbamide-ammonia mixture (CAM). Ahronom 1: 20-2. [in Russian].

Ekin Z. (2019) Integrated Use of Humic Acid and Plant Growth Promoting Rhizobacteria to Ensure Higher Potato Productivity in Sustainable Agriculture. Sustainability. 11(12):3417. https://doi.org/10.3390/su11123417.

Gamayunova VV, Panfilova AV, Averchev OV. (2018) Winter wheat productivity depending on the cultivation technology elements in the Southern Steppe of Ukraine. Taurida Scientific Herald. Series: Rural Sci. 103:16-22.

Ibrahim OM, Wali AM, Elham AB et al. (2016) Response of wheat yield to soil application of humic acid and foliar application of sodium silicate. Res. J. Pharm. Biol. Chem. Sci. 7(4):2003-07.

Ihsanullah D. (2013) Comparative Study of Farm Yard Manure and Humic Acid in Integration with Inorganic-N on Wheat (Triticum aestivum L.) Growth and Yield. Tarim Bilim. Derg. J. Agric. Sci. 19(3):170-77.

Jamal Y, Shafi M, Bakht J. (2011) Effect of seed priming on growth and biochemical traits of wheat under saline conditions. Afr. J. Biotechnol. 10(75):17127-33. https:// doi.org/10.5897/AJB11.2539.

Jarošová M, Klejdus B, Kováčik J et al. (2016) Humic acid protects barley against salinity. Acta Physiol. Plant. 38 (6):161. https://doi.org/10.1007/s11738-016-2181-z.

Karcauskiene D, Repsiene $R$, Ambrazaitiene $D$ et al. (2019) A complex assessment of mineral fertilizers with humic substances in an agroecosystem of acid soil. Zemdirbyste-Agric. 106(4):307-14. https://doi.org/ 10.13080/z-a.2019.106.039.

Kandil AA, Sharief AEM, Seadh SE et al. (2016) Role of humic acid and amino acids in limiting loss of nitrogen fertilizer and increasing productivity of some wheat cultivars grown under newly reclaimed sandy soil. Int. J. Adv. Res. Biol. Sci. 3(4):123-36.

Knapowski T, Szczepanek M, Wilczewski E et al. (2015) Response of Wheat to Seed Dressing with Humus and 


\section{MARENYCH et al.}

Foliar Potassium Fertilization. J. Agric. Sci. Technol. 17(6):1559-69.

Liu ML, Wang C, Wang FY et al. (2019) Vermicompost and humic fertilizer improve coastal saline soil by regulating soil aggregates and the bacterial community. Arch. Agron. Soil. Sci. 65(3):281-93. doi.org/10.1080/036503 40.2018.1498083.

Livandovskyi AA, Khomenko TM, Smulska IV et al. (2016) Metodyka provedennia ekspertyzy sortiv roslyn hrupy zernovykh, krupianykh ta zernobobovykh na prydatnist do poshyrennia v Ukraini/za red. SO Tkachyk. Vinnytsia: FOP Korzun D. Iu. - 82 p. https://www.sops.gov.ua/ uploads/page/5b7d6a4993544.pdf

Muhammad S, Anjum AS, Kasana MI et al. (2013) Impact of organic fertilizer, humic acid and sea weed extract on wheat production in Pothowar region of Pakistan. Pak. J. Agric. Sci. 50(4): 677-81.

Matysiak K, Miziniak W, Kaczmarek $S$ et al. (2018) Herbicides with natural and synthetic biostimulants in spring wheat. Cienc. Rural. 48:11, e20180405. https://doi.org/ 10.1590/0103-8478cr20180405.

Ol'hovs 'kyj GF, Bobro MA, Chechuj OF. (2019) The detailed method for determining the structure of winter wheat crops. Bull. Agric. Sci. 12:22-9. https://doi.org/10.31073/ agrovisnyk201912-03.

Qin Y, Zhu H, Zhang $M$ et al. (2016) GC-MS Analysis of Membrane-Graded Fulvic Acid and Its Activity on Promoting Wheat Seed Germination. Mol. 21(10):1363. https://doi.org/10.3390/molecules21101363.

Rose MT, Patti AF, Little KR et al. (2014) Chapter Two - A Meta-Analysis and Review of Plant-Growth Response to Humic Substances: Practical Implications for Agriculture. Adv. Agron. 124:37-89. https://doi.org/10.1016/B978-012-800138-7.00002-4.

Rodrigues LFOS, Guimarães VF, da Silva MB et al. (2014) Características agronômicas do trigo em função de Azospirillum brasilense, ácidos húmicos e nitrogênio em casa de vegetação. Rev. Bras. Eng. Agríc. Am-bient. 18(1):31-7. https://doi.org/10.1590/S1415-43662014000 100005 .

Rozhkov AO, Puzik VK, Kalenska SM et al. (2016) Doslidna sprava v ahronomii: navch. posibnyk: u 2 kn. - Kn. 1. Teoretychni aspekty doslidnoi spravy. Kh: Maidan, 2016.316 p. http://dspace.knau.kharkov.ua/jspui/bitstream/12
$3456789 / 652 / 1 / \% \mathrm{D} 0 \% 94 \% \mathrm{D} 0 \% \mathrm{BE} \% \mathrm{D} 1 \% 81 \% \mathrm{D} 0 \% \mathrm{BB}$ $\% \mathrm{D} 1 \% 96 \% \mathrm{D} 0 \% \mathrm{~B} 4 \% \mathrm{D} 0 \% \mathrm{BD} \% \mathrm{D} 0 \% \mathrm{~B} 0 \% 20 \% \mathrm{D} 1 \% 81$

$\% \mathrm{D} 0 \% \mathrm{BF} \% \mathrm{D} 1 \% 80 \% \mathrm{D} 0 \% \mathrm{~B} 0 \% \mathrm{D} 0 \% \mathrm{~B} 2 \% \mathrm{D} 0 \% \mathrm{~B} 0 \% 20$

$\%$ D $0 \%$ B 2\% 20\%D0\%90\%D0\%B3\%D1\%80\%D0\%BE\%D0\%BD\%D0\%BE\%D0\%BCi\%D1\%97.pdf

Shah ZH, Rehman HM, Akhtar T et al. (2018) Humic Substances: Determining Potential Molecular Regulatory Processes in Plants. Front Plant Sci 9: 263. https://doi. org/10.3389/fpls.2018.00263.

Sarma B, Buragohain S, Nath DJ et al. (2017) Temporal responses of soil biological characteristics to organic inputs and mineral fertilizers under wheat cultivation in inceptisol. Arch Agron Soil Sci 63(1): 35-47. https://doi. org/10.1080/03650340.2016.1179385.

Shazma A, Iqbal F, Khattak WA et al. (2016) Response of Wheat Crop to Humic Acid and Nitrogen Levels. EC Agriculture 3.1: 558-65.

Soltani N, Shropshire C, Sikkema P. (2015) Effect of Biostimulants Added to Postemergence Herbicides in Corn, Oats and Winter Wheat. Agric. Sci. 6: 527-34. https:// doi.org/10.4236/as.2015.65052.

Trevisan S, Francioso O, Quaggiotti S et al. (2010) Humic substances biological activity at the plant-soil interface. From environmental aspects to molecular factors. Plant Signal Behav 5(6):635-43. https://doi.org/10.4161/ psb.5.6.11211.

Soroka TA, Shchukin VB, Karakulev VV. (2012) Effect of microelements, fertilizers based on humic acids and growth regulators on winter productivity and grain quality. Izvestia Orenburg State Agrarian University 3(35):51-3 [in Russian].

Turgay OC, Karaca A, Unver $S$ et al. (2011) Effects of Coal-Derived Humic Substance on Some Soil Properties and Bread Wheat Yield. Commun. Soil Sci. Plant Anal. 42(9):1050-70. https://doi.org/10.1080/00103624.2011. 562586.

Zhang X, Zhang X, Liu X et al. (2016) Improving Winter Wheat Performance by Foliar Spray of ABA and FA Under Water Deficit Conditions. J. Plant Growth Regul. 35(1):83-96. https://doi.org/10.1007/s00344-015-9509-6.

Zhelyazkov OI. (2015) Effectiveness of nitrogen fertilizer in winter wheat in the conditions of the northern Steppe. Visnyk Zhytomyrskoho natsionalnoho ahroekolohichnoho universytetu. 1(47-1):156-62. 